\title{
The Bacteroid Periplasm in Soybean Nodules Is an Interkingdom Symbiotic Space
}

\author{
Kent N. Strodtman, Severin E. Stevenson, James K. Waters, Thomas P. Mawhinney, Jay J. Thelen, \\ Joseph C. Polacco, and David W. Emerich ${ }^{\dagger}$
}

Department of Biochemistry, University of Missouri, Columbia, MO 65211, U.S.A.

Accepted 17 August 2017.

\begin{abstract}
The functional role of the periplasm of nitrogen-fixing bacteroids has not been determined. Proteins were isolated from the periplasm and cytoplasm of Bradyrhizobium diazoefficiens bacteroids and were analyzed using liquid chromatography tandem mass spectrometry proteomics. Identification of bacteroid periplasmic proteins was aided by periplasm prediction programs. Approximately $40 \%$ of all the proteins identified as periplasmic in the B. diazoefficiens genome were found expressed in the bacteroid form of the bacteria, indicating the periplasm is a metabolically active symbiotic space. The bacteroid periplasm possesses many fatty acid metabolic enzymes, which was in contrast to the bacteroid cytoplasm. Amino acid analysis of the periplasm revealed an abundance of phosphoserine, phosphoethanolamine, and glycine, which are metabolites of phospholipid metabolism. These results suggest the periplasm is a unique space and not a continuum with the peribacteroid space. A number of plant proteins were found in the periplasm fraction, which suggested contamination. However, antibodies to two of the identified plant proteins, histone $\mathrm{H} 2 \mathrm{~A}$ and lipoxygenase, yielded immunogold labeling that demonstrated the plant proteins were specifically targeted to the bacteroids. This suggests that the periplasm is an interkingdom symbiotic space containing proteins from both the bacteroid and the plant.
\end{abstract}

The gram-negative soil bacterium Bradyrhizobium diazoefficiencs (formerly japonicum) (Delamuta et al. 2013) infects soybean (Glycine max) roots, forming a new plant-derived, nitrogen-fixing organ referred to as the nodule. During nodule formation, B. diazoefficiens transforms into a nongrowing, nonmotile form, called a bacteroid, that is retained within a plantderived membrane, the peribacteroid, or peribacteroid membrane within the infected plant cells. Inside the peribacteroid membrane and outside the outer membrane of the bacteroid is the peribacteroid space. Bergersen (1982) estimated that each infected soybean nodule cell was composed of approximately $20 \%$ host cell cytoplasm, $40 \%$ bacteroids, and $40 \%$ peribacteroid space. Between the outer and the inner membranes of gram-negative bacteria resides the periplasmic space, which may constitute 10 to $40 \%$ of the total bacterial cellular volume (Ames 1988). Thus, the periplasm is the smallest of the symbiotic spaces within nodules.

In free-living, gram-negative bacteria, the periplasm consists of a gel-like matrix with hydrolytic enzymes, binding proteins

${ }^{\dagger}$ Corresponding author: David W. Emerich; E-mail: emerichd@missouri.edu

*The $\boldsymbol{e}$-Xtra logo stands for "electronic extra" and indicates that two supplementary figures and one supplementary table are published online.

() 2017 The American Phytopathological Society for transporters, chemoreceptors, and detoxifying enzymes (Ames 1988). The periplasm protein content reflects the cellular environment, which experimentally is usually a defined culture medium. For symbiotic rhizobia, the cellular environment is the peribacteroid space bounded by the peribacteroid membrane within the infected plant cell cytoplasm. Whereas cultured cells receive a prescribed level of nutrients under defined conditions, symbiotic bacteria are subject to the physiological state of the plant host, which can vary both the composition and amount of nutrients. Furthermore, the nutrients received by the plant are only partly known.

Proteomic analyses of the peribacteroid space and peribacteroid membrane have been reported (Catalano et al. 2004; Panter et al. 2000; Saalbach et al. 2002). The peribacteroid membrane-associated proteins were annotated with nonmetabolic functions and were largely of plant origin (Emerich and Krishnan 2014). The peribacteroid space-associated proteins were annotated with metabolic functions and were largely of bacterial origin (Emerich and Krishnan 2014). The peribacteroid compartment is an interkingdom domain populated by proteins from each symbiont (Emerich and Krishnan 2014). However, it is not known whether the periplasmic space is a separate compartment with unique enzyme composition and one or more metabolic functions or is a continuum of the peribacteroid space. Identification of the protein and enzyme composition of each of these symbiotic compartments will help resolve how these spaces integrate nodule function. A complicating issue is that it is difficult to isolate the proteins from bacteroid periplasm, as first, it has a small volume relative to the bacteroid cytoplasm and peribacteroid space, and second, a small amount of contamination by proteins either leaked from the B. diazoefficiens cytosol or by insufficient removal of proteins from the peribacteroid space as well as the infected plant cell cytoplasm can greatly dilute the amount of the periplasmic proteins and. thus, have a profound effect on identification and quantification of proteins originating from the periplasm. Third, the gel-like matrix may retard the release of periplasmic proteins.

Glenn and Dilworth (1979) first demonstrated the ability to separate the periplasmic space from the cytoplasmic space in rhizobia utilizing a lysozyme and EDTA treatment. In 1986, de Maagd and Lugtenberg (1986) demonstrated a refinement of the method to fractionate the outer membrane, cytoplasmic membrane, periplasmic space, and cytoplasmic components of Rhizobium leguminosarum. They were able to release, on average, $88 \%$ of the total alkaline phosphatase activity, a periplasmic marker enzyme, and only 3 to $4 \%$ of the total activity of the cytoplasmic marker enzyme malate dehydrogenase. Protein patterns based on sodium dodecyl sulfate-polyacrylamide gel electrophoresis confirmed the unique protein contents of each fraction, but no identification of the proteins was performed. Subsequently, the periplasmic space of cultured bacteria and 
bacteroids of $B$. diazoefficiens and Rhizobium leguminosarum bv. phaseoli was enzymatically probed after subjecting them to a dilute Triton X-100 treatment (Streeter 1989). Incubation at $\mathrm{pH}$ 4.0 prior to osmotic shock was found to increase the recovery of periplasmic marker enzymes while limiting the contamination of the cytoplasmic marker enzyme malate dehydrogenase from $R$. leguminosarum bv. phaseoli bacteroids at less than $2 \%$ (Streeter and Le Rudulier 1990).

There are few reports documenting metabolic events in the periplasmic space of bacteroids or free-living rhizobia. The periplasmic nitrate reductase from free-living $B$. diazoefficiens oxidizes quinol via the two-electron reduction of $\mathrm{NO}_{3}{ }^{-}$to $\mathrm{NO}_{2}^{-}$, with the quinol oxidation possibly coupled to proton translocation with conservation of energy (Delgado et al. 2003). The results of the study suggested that the periplasmic nitrate reductase was the enzyme responsible for anaerobic growth of free-living $B$. diazoefficiens under nitrate-respiring conditions. Also, B. diazoefficiens bacteroids contain the periplasmic nitrate reductase, which was responsible for the formation of nitrosylleghemoglobin from nitric oxide (Meakin et al. 2007). The nitrosylleghemoglobin compromises leghemoglobin's ability to effectively bind oxygen. Glucose metabolism occurs extracellularly, as shown by Bernardelli et al. (2001) via a periplasmic pyrroloquinoline quinone-dependent glucose dehydrogenase that oxidizes glucose to gluconate in Rhizobium tropici and Sinorhizobium meliloti.

Recent proteomic studies have greatly expanded the understanding of the symbiosis between $B$. diazoefficiens and Glycine max by examining secreted proteins, comparison of nodules from the field and growth chamber, effect on plant hosts, and in in-vitro growth conditions (Batista et al. 2010; Delmotte et al. 2010; Hempel et al. 2009; Koch et al. 2010; Sarma and Emerich 2005, 2006). Several studies have utilized protein prediction to determine subcellular localization (Batista et al. 2010; Delmotte et al. 2010).

To date, no global examination of the periplasmic proteome of $B$. diazoefficiens bacteroids has been undertaken. Here, we describe the refinement of previous techniques (Streeter 1989; Streeter and Le Rudulier 1990) for isolating periplasmic proteins from $B$. diazoefficiens bacteroids and their identification via liquid chromatography tandem mass spectrometry (LCMS/MS). A total of 363 proteins (362 endogenous proteins plus bovine serum albumin as control) were confidently identified in this study, with 93 (48 bacteroid and 45 plant) found in the periplasmic space, 122 (115 bacteroid and seven plant) proteins in the cytoplasmic space, and 147 (146 bacteroid and one plant) proteins in common to both locations. These proteins represent a first step toward defining the bacteroid periplasm proteome.

\section{RESULTS}

The procedure of Streeter (1989) and Streeter and Le Rudulier (1990) was used to isolate the periplasm fraction from B. diazoefficiencs bacteroids isolated from soybean root nodules. The spheroplasts remaining from periplasm isolation were ruptured and the cytoplasmic proteins were prepared for MS analysis.
The contamination of organellar isolations is commonly monitored by the use of marker enzymes to monitor the extent of contamination. The marker enzymes used by Streeter (1989) and Streeter and Le Rudulier (1990) plus isocitrate dehydrogenase were measured to obtain an assessment of purity of the periplasm preparations. Approximately 8 to $10 \%$ of the total phosphodiesterase activity was measured in the periplasmic fraction (Table 1). Malate dehydrogenase activity in the periplasms was 8 to $16 \%$ of total activity, while $\beta$-hydroxybutyrate dehydrogenase activity was 1 to $4 \%$ and isocitrate dehydrogenase activity was 1 to $5 \%$. The enzymatic assessment suggested that the periplasm isolation procedure was effective but still contained bacteroid cytosolic proteins.

Unfortunately, the inclusion of lysozyme at levels used by Streeter (1989) and Streeter and Le Rudulier (1990) obscured proteins present in the periplasm preparations during proteomic mass spectral analysis. Without the addition of lysozyme, too few proteins were released to identify. The use of Ready-lyse (Epicenter), a recombinant lysozyme preparation with 200 -fold higher specific activity than egg-white lysozyme, greatly reduced the amount of enzyme protein added to the bacteroid preparations, increasing the amount of $B$. diazoefficiens proteins released without being obscured by the added lysozyme.

Bioinformatic analysis is a valuable tool for assessing protein localizations (Heazlewood et al. 2005) and confirmed that the isolation procedure recovered periplasmic proteins. Of 48 B. diazoefficiens proteins found only in the periplasmic fraction, 26 were confirmed by a computational prediction program database (cPSORTdb) to be localized to the periplasm (Fig. 1). There were an additional 50 proteins found in the cytoplasmic fraction that cPSORTdb identified as periplasmic. There were 146 B. diazoefficiens proteins found in both the periplasm fraction and the cytoplasm fraction; 48 of the proteins found in both locations were determined by cPSORTdb to be localized to the periplasm, 72 to the cytoplasm, and 26 had an unknown location. Bioinformatic analysis identified a

\section{B. diazoefficiens proteins found in each fraction and their predicted location}

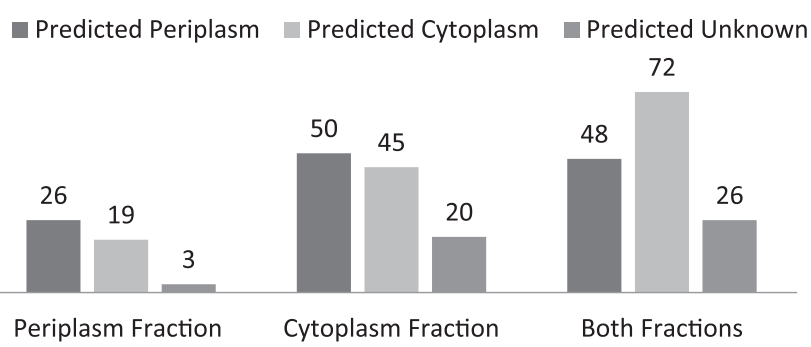

Fig. 1. The number of Bradyrhizobium diazoefficiens bacteroid proteins found in each fraction and their predicted PSORT location. The numbers on the top of each bar are the numbers of proteins found in each biological location (e.g., the periplasm fraction) that were annotated to a cellular location (e.g., the predicted periplasm).

Table 1. Enzyme activity in periplasmic and cytoplasmic fractions of bacteroids isolated from soybean nodules

\begin{tabular}{|c|c|c|c|c|}
\hline \multirow[b]{2}{*}{ Fraction $^{\mathbf{a}}$} & \multirow[b]{2}{*}{ Cyclic-phosphodiesterase ${ }^{b}$} & \multicolumn{3}{|c|}{ Dehydrogenases } \\
\hline & & Malate $^{c}$ & Isocitrate $^{b}$ & $\beta$-Hydroxybutyrate ${ }^{b}$ \\
\hline Periplasm & $0.96 \pm 0.2$ & $0.164 \pm 0.024$ & $2.92 \pm 1.89$ & $4.6 \pm 2.5$ \\
\hline Cytoplasm & $11.4 \pm 1.0$ & $1.98 \pm 0.08$ & $247.4 \pm 25.4$ & $359.47 \pm 20.32$ \\
\hline
\end{tabular}

\footnotetext{
${ }^{a}$ Periplasm and cytoplasm values are the result of three biological replicates measured in triplicate.

b Values are nanomoles per minute per microgram and represent mean \pm standard deviation.

${ }^{c}$ Values are micromoles per minute per microgram and represent mean \pm standard deviation.
} 
total of 124 possible periplasmic proteins, or approximately $40 \%$ of the 306 periplasmic proteins in the $B$. diazoefficiens genome. A total of 95 proteins were identified with $P$ values of 0.05 or lower; of these, 36 were annotated to the cytoplasm, 35 were annotated to the periplasm, 18 were annotated as unknown, and two were annotated to the cytoplasmic membrane (Tables 2 and 3; Supplementary Table S1).

The majority of peptides with the greatest spectral hits were cytoplasmic proteins (Tables 2 and 3). Of the 24 proteins with spectral counts of 10 or greater, 14 were predicted to be cytoplasmic, nine periplasmic, and two with unknown localization. A large majority of peptides with spectral counts greater than four were found in both compartments. The majority of the proteins found in the periplasmic fraction had spectral counts of two. The chosen selection criterion minimum was two peptides.

Surprisingly, 53 proteins identified in this study were not from $B$. diazoefficiens but were annotated as plant proteins (Table 4). Of the 93 proteins identified in the periplasm, 48 were annotated as $B$. diazoefficiens proteins and 45 as plant proteins. Thus, about half of all the proteins isolated from the periplasm were identified as plant proteins. Seven plant proteins were found associated with the bacteroid cytoplasm and one plant protein was found in both locations. Curiously, of the 53 plant proteins identified, none were leghemoglobin, which is the most abundant protein in soybean nodules (Anthon and

Table 2. Bradyrhizobium diazoefficiens proteins participating in amino acid metabolism in the bacteroid periplasm and cytoplasm ${ }^{\mathrm{a}}$

\begin{tabular}{|c|c|c|c|c|c|c|}
\hline Protein identified & Rhizobase & Accession & Location $^{\mathbf{b}}$ & Predicted location & Unique peptides ${ }^{c}$ & $\%$ Coverage $^{d}$ \\
\hline Isopropylmalate isomerase large subunit ${ }^{\mathrm{LA} *}$ & blr0488 & NP_767128 & Periplasm & Cytoplasm & $2(3)$ & 5 \\
\hline Alanine racemase $\mathrm{AC}_{*}$ & bll4070 & NP_770710 & Periplasm & Cytoplasm & $2(2)$ & 4 \\
\hline Cysteine desulfurase (nifS) ${ }^{\mathrm{AA}}$ & blr4342 & NP_770982 & Periplasm & Cytoplasm & $2(2)$ & 9 \\
\hline $\begin{array}{l}\text { Propionyl-coenzyme A carboxylase alpha } \\
\text { subunit }^{\mathrm{IC}}\end{array}$ & bl15267 & NP_771907 & Periplasm & Cytoplasm & 4(4) & 13 \\
\hline $\begin{array}{l}\text { DegT/DnrJ/EryC1/StrS aminotransferase } \\
\text { family }\end{array}$ & blr5428 & NP_772068 & Periplasm & Cytoplasm & $2(2)$ & 13 \\
\hline$\underline{S}$-adenosylmethionine synthetase ${ }^{\mathrm{MC} *}$ & bl15945 & NP_772585 & Periplasm & Cytoplasm & $2(2)$ & 12 \\
\hline$\overline{\text { Ägmatine amidohydrolase }}$ & blr5691 & NP_772331 & Periplasm & Cytoplasm & $2(2)$ & 10 \\
\hline Probable acetolactate synthase $\mathrm{I}^{\mathrm{IA}, \mathrm{LA}, \mathrm{VA}, \mathrm{P}}$ & bl17231 & NP_773871 & Periplasm & Cytoplasm & $2(2)$ & 7 \\
\hline Aminopeptidase & bll7941 & NP_774581 & Periplasm & Unknown & $2(2)$ & 11 \\
\hline Tryptophan synthase subunit beta ${ }^{\text {WA,P }}$ & blr0745 & NP_767385 & Cytoplasm & Unknown & $3(3)$ & 13 \\
\hline Putative aminotransferase $\mathrm{P}^{\mathrm{P}}$ & blr2136 & NP_768776 & Cytoplasm & LipoP & $2(2)$ & 12 \\
\hline Ornithine aminotransferase $\mathrm{e}^{\mathrm{OC}, \mathrm{PA}, \mathrm{P}}$ & blr3010 & NP_769650 & Cytoplasm & Cytoplasm & $2(2)$ & 7 \\
\hline Amidohydrolase $\mathrm{P}^{\mathrm{P}}$ & blr3021 & NP_769661 & Cytoplasm & Cytoplasm & $2(2)$ & 13 \\
\hline $\begin{array}{l}\text { Succinyl-diaminopimelate desuccinylase } \\
(\text { dapE })^{\mathrm{KA}}\end{array}$ & blr3064 & NP_769704 & Cytoplasm & Unknown & $2(2)$ & 12 \\
\hline $\begin{array}{l}\text { Probable arginine/lysine/ornithine } \\
\text { decarboxylases } \mathrm{RC,KC,OC,P}\end{array}$ & bl13177 & NP_769817 & Cytoplasm & Unknown & $2(2)$ & 4 \\
\hline Possible lysine decarboxylase $\mathrm{e}^{\mathrm{KC}, \mathrm{P}}$ & bl13794 & NP_770434 & Cytoplasm & Unknown & $2(3)$ & 26 \\
\hline Aminotransferase $* \mathrm{P}$ & blr4134 & NP_770774 & Cytoplasm & Unknown & 2(4) & 8 \\
\hline $\mathrm{L}$-asparaginase $\mathrm{NC}^{\mathrm{NC}, \mathrm{DA}, \mathrm{LS} *, \mathrm{P}}$ & bl14950 & NP_771590 & Cytoplasm & TatP, LipoP & $2(2)$ & 11 \\
\hline Methionine sulfoxide reductase $\mathrm{A}^{\mathrm{MA}, \mathrm{P}}$ & bl16260 & NP_772900 & Cytoplasm & Cytoplasm & $2(2)$ & 19 \\
\hline Ketol-acid reductoisomerase $\mathrm{e}^{\mathrm{IA}, \mathrm{P}}$ & bl16497 & NP_773137 & Cytoplasm & Cytoplasm & $2(2)$ & 9 \\
\hline Aspartate aminotransferase ${ }^{\mathrm{DC} *, \mathrm{P}}$ & bl17416 & NP_774056 & Cytoplasm & Cello & $2(2)$ & 8 \\
\hline $\begin{array}{l}\text { 1-Aminocyclopropane-1-carboxylate } \\
\text { deaminase }\end{array}$ & blr0241 & NP_766881 & Both & Unknown & $8(8) / 3(5)$ & 37 \\
\hline Isopropylmalate isomerase small subunit ${ }^{\mathrm{LA}}$ & blr0495 & NP_767135 & Both & Unknown & $3(3) / 3(4)$ & 31 \\
\hline Aspartate-semialdehyde dehydrogenase $\mathrm{KA}^{\mathrm{KA}}$ & bl10501 & NP_767141 & Both & Unknown & $2(2) / 2(5)$ & 14 \\
\hline 3-Isopropylmalate dehydrogenase ${ }^{\mathrm{IA} *}$ & bl10504 & NP_767143 & Both & Cytoplasm & $3(4) / 3(3)$ & 18 \\
\hline Aminotransferase* & blr1686 & NP_768326 & Both & Unknown & $16(19) / 22(37)$ & 49 \\
\hline Anthranilate phosphoribosyltransferase ${ }^{\mathrm{WA} *}$ & bl12049 & NP_768689 & Both & Cytoplasm & $2(3) / 2(3)$ & 15 \\
\hline $\begin{array}{l}\text { N5-methylenetetrahydropteroyltriglutamate- } \\
\text { homocysteine methyltransferase }\end{array}$ & blr2068 & NP_768708 & Both & Cytoplasm & $2(3) / 5(8)$ & 14 \\
\hline $\begin{array}{l}S \text {-adenosyl-L-methionine-dependent } \\
\text { methyltransferases family }\end{array}$ & blr2372 & NP_769012 & Both & Cytoplasm & $2(2) / 5(8)$ & 20 \\
\hline Glutaryl-CoA dehydrogenase ${ }^{\mathrm{LC}, \mathrm{WC}}$ & blr2616 & NP_769256 & Both & Unknown & $4(5) / 4(6)$ & 16 \\
\hline $\begin{array}{l}\text { Alanine dehydrogenase oxidoreductase } \\
\text { protein }^{\mathrm{AC}}\end{array}$ & blr3179 & NP_769819 & Both & Cytoplasm & $2(2) / 2(2)$ & 16 \\
\hline $\begin{array}{l}\text { Fumarylacetoacetate hydrolase } \\
\text { superfamily }\end{array}$ & blr3199 & NP_769839 & Both & Adaboost, Cello & $2(2) / 2(3)$ & 8 \\
\hline 3-Hydroxyisobutyrate dehydrogenase ${ }^{\mathrm{VC}}$ & bl13740 & NP_770380 & Both & Cytoplasm & $2(2) / 2(3)$ & 17 \\
\hline $\begin{array}{l}\text { Methylmalonate-semialdehyde } \\
\text { dehydrogenase }^{\mathrm{VC} *}\end{array}$ & blr3954 & NP_770594 & Both & Cytoplasm & $3(3) / 2(4)$ & 14 \\
\hline Glutamine synthetase $\mathrm{I}^{\mathrm{QA} *}$ & blr4949 & NP_771589 & Both & Cello & $4(6) / 7(11)$ & 31 \\
\hline$O$-acetylhomoserine sulfhydrylase $\mathrm{MA}^{\mathrm{MA}}$ & blr4967 & NP_771607 & Both & LipoP & $3(3) / 2(4)$ & 13 \\
\hline Serine hydroxymethyltransferase $\mathrm{SC}^{\mathrm{SC}, \mathrm{GA}}$ & bl15033 & NP_771673 & Both & Cytoplasm & $5(7) / 5(8)$ & 22 \\
\hline$S$-adenosyl-L-homocysteine hydrolase ${ }^{\mathrm{MC}}$ & bl15944 & NP_772584 & Both & Unknown & $2(2) / 2(3)$ & 16 \\
\hline Glutamate synthase large subunit ${ }^{\mathrm{EA}}$ & blr7743 & NP_774383 & Both & Cytoplasm & $3(3) / 3(3)$ & 8 \\
\hline Homospermidine synthase $\mathrm{R}^{\mathrm{RC}}$ & blr7762 & NP_774402 & Both & Cello & $2(2) / 2(3)$ & 5 \\
\hline
\end{tabular}

${ }^{a}$ The first superscript letter indicates the one-letter abbreviation of each specific amino acid and the second letter indicates anabolic (A) or catabolic (C). Proteins with leader sequences are designated by the superscript ${ }^{\mathrm{LS}}$; asterisks $(*)$ denote proteins identified by Sarma and Emerich $(2005)$; P denotes a $P$ value of $\leq 0.05$.

b When peptides were found in both locations, the ratio indicates the number of peptides identified (spectral counts) in the periplasm relative to those identified in the cytoplasm.

c Spectral counts are shown in parentheses. Number of unique peptides and spectral counts are from one of the six determinations (three biological replicates, two technical replicates per biological replicate).

$\mathrm{d}$ The average of all determinations rounded to the nearest whole number. 
Emerich 1990; Copeland et al. 1989; Kouchi et al. 1988; Oehrle et al. 2008). The absence of leghemoglobin allowed the suggestion that the plant proteins may be specifically translocated to the periplasm. To test for this possibility, histone $\mathrm{H} 2 \mathrm{~A}$ and lipoxygenase were chosen for cytolocalization. Histone H2A was chosen because it was the plant protein that yielded the greatest percent coverage. Lipoxygenase was chosen because it was one of the two plant proteins that yielded three peptide fragments. Western blot analysis of periplasm preparations gave a positive response for the presence of histone $\mathrm{H} 2 \mathrm{~A}$ and lipoxygenase in the periplasmic fraction (Supplementary Fig. S1). Immunogold labeling was found predominately associated with the bacteroid surface, consistent with periplasmic localization (Fig. 2). There was little labeling within the plant cytoplasm in either infected or uninfected cells. Lipoxygenase activity in periplasm extracts at $\mathrm{pH} 9.0$ was $449 \mu$ moles/min per milligram of protein; no activity was detected at $\mathrm{pH}$ 6.5. A pH optimum of 9 is indicative of type 1 lipoxygenases (Mohammadi and Karr 2003).

A total of 362 proteins (not including bovine serum albumin [BSA] as internal control) were identified in the LC-MS/MS analysis: 93 in the periplasmic fraction (48 bacteroid proteins plus 45 plant proteins), 122 in the cytosolic fraction (115 bacteroid proteins plus seven plant proteins) and 147 common to both fractions (146 bacteroid proteins plus one plant protein) (Fig. 1; Table 4). The average number of peptides identified for all proteins in this study was approximately 3.3. The average number of peptides for proteins predicted to be localized in the bacteroid cytoplasm was approximately 2.4. The average number of peptides for proteins predicted to be in the periplasm was approximately 2.0. The number of unique peptides per protein for proteins found in the periplasm fraction only (approximately 2.1 ) or cytoplasm fraction only (approximately 2.3) were each less than half the number of those found in both fractions (approximately 4.8). Each of the 26 proteins found and localized to the periplasm was identified by only two peptides and had an average of $11.8 \%$ coverage. The percent coverage of all proteins identified in this study was $16.5 \%$. The percent coverage of all proteins minus the periplasmic proteins was $17 \%$. The proteins identified as peribacteroid space proteins yielded an average of 7.2 unique peptides and $29.8 \%$ coverage.

Each of the marker enzymes used to validate the periplasm isolation were identified in the mass spectral analysis. A type I phosphodiesterase (blr5306) was found in the cytoplasmic fraction, but bioinformatics analysis placed it in the periplasm (two peptides identified; $4.1 \%$ coverage). Malate dehydrogenase (bll0456) was found in both fractions but was predicted to be localized to the cytoplasm (10 peptides; $52 \%$ coverage). $\beta$-Hydroxybutryate dehydrogenase (bll1488) was found in both fractions but was predicted to be localized to the periplasm (three peptides; $21 \%$ coverage). Isocitrate dehydrogenase (blr5747) was found in both fractions but the predicted location was listed as unknown (three peptides; $13 \%$ coverage).

A total of $31 \mathrm{~B}$. diazoefficiens proteins identified here as periplasmic proteins were found to have leader sequences as determined by the computation prediction program Signal $\mathrm{P}$ (Fig. 3). The leader sequence had an abundance of alanine and leucine residues and an alanine residue was greatly favored as the first residue $\mathrm{C}$-terminal to the cleavage site. The cleavage site was located near the $\mathrm{C}$-terminal portion of a predicted helix. Of the proteins identified to have signal sequences, 21 were categorized as transport and binding proteins. The remainder of the proteins with a leader sequences were in the other and hypothetical/unknown protein categories, with the exception of a phospholipase/carboxyesterase (bll1566), a putative alcohol dehydrogenase (bll6220), an L-asparaginase (bll4950), and an OmpA family protein (blr0521).

Each protein was placed into the functional categories of Kaneko et al. (2002). The categories of amino acid metabolism (Table 2) and fatty acid metabolism (Table 3) are described in the following paragraphs.

There were 40 proteins identified in the amino acid metabolism category, making it among the more abundant categories in this study. The amino acid metabolism category had an average

Table 3. Bradyrhizobium diazoefficiens proteins participating in fatty acid metabolism in the periplasm and cytoplasm ${ }^{\mathrm{a}}$

\begin{tabular}{|c|c|c|c|c|c|c|}
\hline Protein identified & Rhizobase & Accession & Localization $^{\mathbf{b}}$ & Predicted localization & Unique peptides $^{c}$ & $\%$ Coverage $^{\mathrm{d}}$ \\
\hline $\begin{array}{l}\text { Acetyl-CoA carboxylase carboxyltransferase } \\
\text { subunit alpha }\end{array}$ & blr0191 & NP_766831 & Periplasm & cPSORTdb & 2(2) & 18 \\
\hline Glycerol kinase & blr1410 & NP_768050 & Periplasm & Unknown & $2(2)$ & 8 \\
\hline Phospholipase/carboxylesterase ${ }^{\mathrm{LS}}$ & bl11566 & NP_768206 & Periplasm & LipoP & $2(2)$ & 13 \\
\hline Acetyl-CoA acetyltransferase & blr3924 & NP_770564 & Periplasm & Cello & $2(2)$ & 11 \\
\hline Fatty oxidation complex alpha subunit & bl17821 & NP_774461 & Periplasm & Unknown & $2(2)$ & 8 \\
\hline $\begin{array}{l}\text { Putative 3-oxoacyl-[acyl-carrier protein] } \\
\text { reductase }\end{array}$ & blr5618 & NP_772258 & Periplasm & Cello, Adaboost, LipoP & $2(3)$ & 13 \\
\hline Acetyl-CoA synthetase ${ }^{P}$ & blr0573 & NP_767213 & Cytoplasm & Cello & $2(2)$ & 6 \\
\hline $\begin{array}{l}\text { Putative 3-oxoacyl-[acyl-carrier protein] } \\
\text { reductase }\end{array}$ & blr7888 & NP_774528 & Cytoplasm & Cytoplasm & $3(3)$ & 14 \\
\hline Enoyl Co-A hydratase/isomerase family ${ }^{P}$ & blr1080 & NP_767720 & Cytoplasm & Cytoplasm & $2(2)$ & 8 \\
\hline Acyl-CoA dehydrogenase*P & blr1158 & NP_767798 & Cytoplasm & TatP & $2(2)$ & 7 \\
\hline Acyl-CoA dehydrogenase *P & bl12657 & NP_769297 & Cytoplasm & Unknown & $2(2)$ & 6 \\
\hline Enoyl CoA hydratase & bl13036 & NP_769676 & Cytoplasm & Cytoplasm & 2(3) & 11 \\
\hline Enoyl-CoA hydratase ${ }^{P}$ & bl16081 & NP_772721 & Cytoplasm & Unknown & $3(3)$ & 22 \\
\hline Acetyl-CoA acetyltransferase ${ }^{P}$ & bl17400 & NP_774040 & Cytoplasm & TatP & $2(5)$ & 11 \\
\hline Acetoacetate decarboxylase family & blr0028 & NP_766668 & Both & Cytoplasmic membrane & $3(3) / 4(6)$ & 32 \\
\hline Acetyl-CoA acetyltransferase & blr1159 & NP_767799 & Both & Cytoplasm & $3(4) / 2(3)$ & 14 \\
\hline Enoyl-CoA hydratase & blr1160 & NP_767800 & Both & Cello & $2(2) / 2(3)$ & 12 \\
\hline 3-Hydroxybutyrate dehydrogenase* & blr1488 & NP_768128 & Both & TatP, LipoP & $2(2) / 2(4)$ & 21 \\
\hline 3-Oxoacyl-(acyl carrier protein) synthase II & bl13808 & NP_770448 & Both & Cello, LipoP & $2(2) / 2(3)$ & 12 \\
\hline 3-Oxoacyl-(acyl carrier protein) synthase II & bl13809 & NP_770449 & Both & Unknown & $2(2) / 2(3)$ & 23 \\
\hline
\end{tabular}

${ }^{\text {a }}$ Proteins with leader sequences are designated by the superscript ${ }^{\mathrm{LS}}$; asterisks $(*)$ denote proteins identified by Sarma and Emerich (2005); P denotes a $P$ value of $\leq 0.05$.

$\mathrm{b}$ When peptides were found in both locations, the ratio in the Unique hits (spectral counts) column indicates the number of peptides identified (spectral counts) in the periplasm relative to those identified in the cytoplasm.

${ }^{\mathrm{c}}$ Spectral counts are shown in parentheses. Number of unique peptides and spectral counts are from one of the six determinations (three biological replicates, two technical replicates per biological replicate).

$\mathrm{d}$ The average of all determinations rounded to the nearest whole number. 
of approximately 3.3 unique peptides per protein and an average of approximately $14.7 \%$ coverage (Table 2 ). There were nine proteins in this category found in the periplasm fraction, but more than half of the proteins (18 of 31) found in the bacteroid cytoplasm or in both fractions yielded localization predictions that implied they were periplasm-located proteins. The metabolic pathways for many of the amino acids were well-represented in this study. A total of 17 proteins involved in the metabolism of nonpolar amino acids were identified among the 40 total proteins involved in amino acid metabolism and the majority (13 or /17) were annotated as cytoplasmic proteins. In contrast, about half ( 9 of 19) of the proteins annotated as periplasmic or unknown were related to charged or aromatic amino acids and the remainder were polar and nonpolar amino acids (Table 2). Two additional proteins could be included, glycerate dehydrogenase (bll2918) and D-phophoglycerate dehydrogenase (bll7965), which were placed in the central intermediary metabolism category due to the possibility of participating in glyoxylate metabolism, as well as glycine, serine, or threonine metabolism. Propionyl-CoA carboxylase alpha subunit was found exclusively in the periplasm and displayed the greatest number of peptide fragments of any of the periplasm-located proteins. Only one protein in this category was identified to have a leader sequence (bll4950, L-asparaginase). The most abundant amino acids found in the periplasm were phosphoethanolamine, phosphoserine, and glycine (Table 5).

The fatty acid metabolism category had an average of 2.6 unique peptides per protein and an average of $13.9 \%$ coverage (Table 3). Many of the enzymes of fatty acid metabolism identified here yielded predicted locations that were periplasmic or unknown. Only three of the proteins identified in this category were found in the bacteroid cytoplasm, and their cytoplasmic localization was supported by bioinformatics analysis. The identified proteins comprised both anabolic and catabolic enzymes of basic fatty acid metabolism. There were no proteins for sterol anabolism/catabolism or membrane lipid anabolism/catabolism. None of the identified proteins in this category had a leader sequence.

\section{DISCUSSION}

The isolation of proteins from the periplasm of soybean nodule bacteroids has the same inherent problems as organelle isolations, that is, contamination from the surrounding cellular milieu, the peribacteroid space, and the host plant cell cytoplasm, but, in addition, there is leakage or rupture of the bacteroids, which contributes cytoplasmic proteins. Bacteroid cytoplasmic proteins are about 10 times more abundant then periplasmic proteins, both in terms of number and in mass, and the volume of the cytoplasm is many times greater than that of the periplasm (Quan et al. 2013). In soybean nodules, the peribacteroid space and the plant cell cytoplasm have much greater volumes than that of the periplasm. This large difference in volume and the greater protein content provide inherent experimental difficulties for isolation of the periplasm. Bioinformatics can provide an independent assessment to complement subcellular isolation. Experimental determination of a protein to the periplasm plus bioinformatics confirmation authenticates the proteins location and validates the isolation procedure. However, given the experimental issues, many proteins may have been found in subcellular locations that differ from their bioinformatics annotation or may have been found in both the bacteroid cytoplasmic and periplasmic fractions.

Comparison of the subcellular fraction reported here showed that periplasmic proteins were underrepresented in previous global proteomic analyses of $B$. diazoefficiens bacteroids. Both Sarma and Emerich (2005) and Delmotte et al. (2010) identified about $10 \%$ of the total proteins present in their extracts as periplasmic proteins. The periplasm extraction procedure resulted in the identification of approximately $35 \%$ of the total proteins as periplasmic proteins. Approximately $16 \%$ of the proteins found here were classified with an unknown location. The periplasm extraction procedure results in a relative enrichment of periplasmic proteins but it also demonstrates the difficulty in identifying periplasmic proteins, due to the protein concentration difference between the bacteroid cytoplasm and periplasm (Quan et al. 2013), and the additional steps required to remove the bacteroids from the nodule. The limitations of the procedure are represented in the low spectral counts of the proteins both found in the periplasm and those predicted to be located there (approximately two spectral counts) relative to the spectral counts of the predicted bacteroid cytoplasmic proteins (approximately four spectral counts). This is probably an inherent limitation of any procedure to isolate periplasmic proteins, because of the low volume of the periplasm. Considering the large excess of bacteroid cytoplasmic proteins relative to periplasmic proteins (Quan et al. 2013), the periplasm isolation procedure utilized in this study plus the use of bioinformatics identified the proteins of the $B$. diazoefficiens bacteroid periplasm.

Alternatively, many proteins have unknown or ambiguous locations. As an example, isocitrate dehydrogenase has been presumed cytoplasmic due to its role in citric acid cycle function, yet bioinformatics analysis lists its location as unknown (PSORT). Curiously, it was found in both the cytoplasm and periplasm. A number of common proteins have been identified as 'moonlighting', that is, as proteins that perform roles, unrelated to their annotated activities, that are displayed in different physiological environments (Emerich and Krishnan 2014; Jeffery 1999). Many of the bacterial moonlighting proteins have been shown to perform roles in virulence (Henderson and Martin 2011). Moonlighting proteins are considered to be ancient gene products (Henderson and Martin 2011), as is nitrogenase and the nitrogen fixation process (Fani et al. 2000; Fennel et al. 2005; Kasting and Siefert 2001). Bacteroid cytoplasmic proteins located in the periplasm and peribacteroid space (Saalbach et al.2002) could have extracellular functions or could be the result of contamination. Moonlighting proteins would not be identified by current localization algorithms. Thus, combining global proteomic analysis (Delmotte et al. 2010; Koch et al. 2010; Sarma and Emerich 2005), bioinformatics, and subcellular preparations provides a better physiological understanding of symbiotic compartmental functioning.

A total of 124 periplasmic proteins were identified in this study, which is about $40 \%$ of the 306 periplasmic proteins identified by cPSORTdb among the 8,453 open reading frames of $B$. diazoefficiens. This total excludes proteins found in the periplasm but annotated to the cytoplasm and, thus, some of these proteins may eventually be found to function in the periplasm. A number of periplasm proteomes have been reported from bacteria that associate with eukaryotes, such as Xanthomonas citri (Artier et al. 2017), Escherichia coli (Heidary et al. 2014), and Pseudomonas aeruginosa (Imperi et al. 2009); unfortunately, they were grown in culture on defined media prior to isolation of the periplasmic proteins. These reports selectively isolated proteins from two-dimensional gels and identified 50 to 100 periplasmic proteins. Escherichia coli is estimated to have approximately 400 periplasmic proteins (Franzén et al. 1999). It has been estimated that $38 \%$ of the proteins of Pseudomonas aeruginosa (approximately 2,000 proteins) are secreted (Imperi et al. 2009).

Considering that the bacteroid is a nongrowing cellular form that is provided nutrients from the plant and is dedicated to the sole task of symbiotic nitrogen fixation, the number of 
periplasmic proteins suggests an active and significant role for the periplasm in symbiosis. Also, some of the 49 proteins (about $16 \%$ of all proteins identified) with unknown localization could be periplasmic proteins. The annotated periplasmic proteins found in the bacteroid cytoplasm fraction may have been more tightly associated with the cytoplasmic or outer membranes or more tightly embedded in the gel-like matrix and only released upon cellular rupture.

Koch et al. (2010) reported the comparative proteomic analysis of B. diazoefficiens in nodules of soybean, cowpea, and siratro. They reported Blr2168 and Blr2169, the subunits of a putative transketolase, were uniquely expressed in soybean. These proteins were found in the bacteroid cytoplasm in this study but were annotated to the cytoplasmic membrane and periplasm, respectively. This suggests that these proteins uniquely expressed in soybean may function in the bacteroid periplasm.

Approximately $15 \%$ of the bacteroid proteins identified in this report originated from the symbiotic island and eight of these proteins yielded more than six unique peptides. The symbiotic island proteins were predominately those involved in

Table 4. Plant proteins found in the Bradyrhizobium diazoefficiens periplasm or cytoplasmic fraction, or both ${ }^{\mathrm{a}}$

\begin{tabular}{|c|c|c|c|c|}
\hline Protein identified & Accession & Location & $\begin{array}{l}\text { Unique peptides } \\
\text { (spectral counts) }^{\text {a }}\end{array}$ & $\%$ coverage $^{b}$ \\
\hline $\begin{array}{l}\text { Histone } \mathrm{H} 2 \mathrm{~B} \text {, putative (Arabidopsis } \\
\text { thaliana) }\end{array}$ & gi|15231854|ref|NP_190933.1| & Periplasm & $2(7)$ & 18 \\
\hline P49 (Indian peanut clump virus D) & gi|27462596|gb|AAO15494.1|AF447396_3 & Periplasm & $2(5)$ & 9 \\
\hline $\begin{array}{l}\text { Histone } \mathrm{H} 2 \mathrm{~A} \text {, putative (Arabidopsis } \\
\text { thaliana) }\end{array}$ & gi|15241857|ref|NP_195876.1| & Periplasm & $2(3)$ & 22 \\
\hline $\begin{array}{l}\text { Histone } \mathrm{H} 2 \mathrm{~A} \text {, putative (Arabidopsis } \\
\text { thaliana) }\end{array}$ & gi|15237024|ref|NP_194453.1| & Periplasm & $2(3)$ & 25 \\
\hline $\begin{array}{l}\text { Chain A, Complex of the second kunitz } \\
\text { domain of tissue factor pathway inhibitor } \\
\text { with porcine trypsin }\end{array}$ & gi|2914482|pdb|1TFX|A & Periplasm & $2(2)$ & 13 \\
\hline $\begin{array}{l}\text { Glycine-rich protein GRP17 (Arabidopsis } \\
\text { thaliana) }\end{array}$ & gi|15081223|gb|AAK83835.1| & Periplasm & $2(2)$ & 12 \\
\hline $\begin{array}{l}\text { Histone } \mathrm{H} 2 \mathrm{~B} \text {, putative (Arabidopsis } \\
\text { thaliana) }\end{array}$ & gi|15237148|ref|NP_197679.1| & Periplasm & $2(3)$ & 21 \\
\hline $\begin{array}{l}\text { Seed lipoxygenase, gi|18746|emb| } \\
\text { CAA39604.1| lipoxygenase (Glycine max) }\end{array}$ & gi|126411|sp|P24095|LOXX_SOYBN & Periplasm & $3(3)$ & 5 \\
\hline $\begin{array}{l}\text { Uricase-2 isozyme } 1 \text { (Uricase II isozyme 1) } \\
\text { (Urate oxidase) (Nodulin 35) (N-35) } \\
\text { (Nodule-specific uricase) }\end{array}$ & gi|549169|sp|P04670|URIC1_SOYBN & Periplasm & $2(2)$ & 18 \\
\hline $\begin{array}{l}\text { Pentatricopeptide repeat-containing protein } \\
\text { (Arabidopsis thaliana) }\end{array}$ & gi|15217470|ref|NP_177298.1| & Periplasm & $2(2)$ & 7 \\
\hline $\begin{array}{l}\text { Histone } \mathrm{H} 2 \mathrm{~A} \text {, putative (Arabidopsis } \\
\text { thaliana) }\end{array}$ & gi|15221875|ref|NP_175868.1| & Periplasm & $2(2)$ & 23 \\
\hline $\begin{array}{l}\text { ATP synthase subunit alpha, mitochondrial, } \\
\text { gi|22739|emb|CAA78407.1| atpA (Glycine } \\
\text { max) }\end{array}$ & gi|231585|sp|Q01915|ATPAM_SOYBN & Periplasm & $2(2)$ & 9 \\
\hline $\begin{array}{l}\text { Protein transport protein } \operatorname{Sec} 24 \text {, putative } \\
\text { (Arabidopsis thaliana) }\end{array}$ & gi|30680129|ref|NP_187366.2| & Periplasm & $2(2)$ & 4 \\
\hline Unknown protein (Arabidopsis thaliana) & gi|15229172|ref|NP_190528.1| & Periplasm & $2(2)$ & 8 \\
\hline $\begin{array}{l}\text { ATMRP7 (Arabidopsis thaliana multidrug } \\
\text { resistance-associated protein 7) }\end{array}$ & gi|30682486|ref|NP_187917.3| & Periplasm & $2(2)$ & 2 \\
\hline $\begin{array}{l}\text { FAT domain-containing protein / } \\
\text { phosphatidylinositol 3- and 4-kinase family } \\
\text { protein (Arabidopsis thaliana) }\end{array}$ & gi|22329206|ref|NP_680770.1| & Periplasm & $2(2)$ & 2 \\
\hline $\begin{array}{l}\text { Protein kinase family protein (Arabidopsis } \\
\text { thaliana) }\end{array}$ & gi|15242791|ref|NP_200569.1| & Periplasm & $3(3)$ & 6 \\
\hline Band 7 family protein (Arabidopsis thaliana) & gi|15241939|ref|NP_201080.1| & Periplasm & $2(2)$ & 10 \\
\hline $\begin{array}{l}\text { Preprotein translocase subunit secA, } \\
\text { chloroplast precursor }\end{array}$ & gi|17369638|sp|Q9SYI0|SECA_ARATH & Periplasm & $2(2)$ & 5 \\
\hline $\begin{array}{l}\text { Ferredoxin-dependent glutamate synthase } 2 \text {, } \\
\text { chloroplast precursor (Fd-GOGAT 2) }\end{array}$ & gi|12643859|sp|Q9T0P4|GLTB2_ARATH & Periplasm & $2(2)$ & 3 \\
\hline $\begin{array}{l}\text { Arginosuccinate synthase family } \\
\text { (Arabidopsis thaliana) }\end{array}$ & gi|22328910|ref|NP_194214.2| & Periplasm & $2(2)$ & 9 \\
\hline Hypothetical protein (Arabidopsis thaliana) & gi|5262196|emb|CAB45793.1| & Periplasm & $2(2)$ & 29 \\
\hline Chaperonin, putative (Arabidopsis thaliana) & gi|30685604|ref|NP_850203.1| & Periplasm & $2(2)$ & 6 \\
\hline $\begin{array}{l}\text { Probable aminopeptidase F24D7.4 } \\
\text { (imported), Arabidopsis thaliana }\end{array}$ & gi|25289686|pir||G96662 & Periplasm & $2(2)$ & 5 \\
\hline Unknown protein (Arabidopsis thaliana) & gi|17065080|gb|AAL32694.1| & Periplasm & $2(2)$ & 6 \\
\hline $\begin{array}{l}\text { EF-TU receptor; ATP binding/kinase/protein } \\
\text { serine/threonine kinase (Arabidopsis } \\
\text { thaliana) }\end{array}$ & gi|15241369|ref|NP_197548.1| & Periplasm & $2(2)$ & 5 \\
\hline $\begin{array}{l}\text { RPM1 (Resistance to P. syringae } \mathrm{pv} \\
\text { maculicola } 1)(\text { Arabidopsis thaliana) }\end{array}$ & gi|15231371|ref|NP_187360.1| & Periplasm & $2(2)$ & 6 \\
\hline Retrovirus-related like polyprotein & gi|2244802|emb|CAB10225.1| & Periplasm & $2(2)$ & 3 \\
\hline
\end{tabular}

(Arabidopsis thaliana)

\footnotetext{
${ }^{a}$ Number of unique peptides and spectral counts are from one of the six determinations (three biological replicates, two technical replicates per biological replicates).

b The average of all determinations rounded to the nearest whole number.
} 
the nitrogen fixation process, including the nitrogenase component proteins. The component proteins of nitrogenase, nifH, nifD, and nifK, were found both in the cytoplasm and the periplasm. Bioinformatics analysis listed an unknown location for nifK and nifH, and both of these proteins previously have been found in the peribacteroid space by Saalbach et al. (2002). It is not known if either the periplasm, the peribacteroid space, or both have the metabolic capacity to provide the necessary MgATP or reduced ferredoxin for nitrogenase catalysis. Nor is it known if these proteins in these extracellular spaces contain their metal cofactors or are present as apoproteins.

There were 13 proteins identified that encoded for common functions with those found in the peribacteroid space of pea nodules (Saalbach et al. 2002). Bacteroid proteins destined for the peribacteroid space would have to transect the periplasm. Eleven of the thirteen peribacteroid space-identified proteins were found in both locations and the remaining two proteins were found only in the bacteroid cytoplasm. Six of the proteins were annotated as periplasmic or unknown proteins. Ten of the thirteen involve interaction with either ATP (two via NAD) or GTP and one of the two remaining peribacteroid space proteins has a pyrimidine binding motif (blr2169). The significance of this common nucleotide binding ability is not known.

The 40 proteins identified in the amino acid metabolism category made it one of the more abundant categories in this study, accounting for 17 of the protein amino acids (Tables 3 and 5) and for all five amino acids needed for peptidoglycan synthesis. The large majority of the proteins in this category were annotated cytoplasmic proteins and only seven proteins assigned to the amino acid metabolism category had annotations localizing them to the periplasm, but 12 were annotated as unknown. There was a distinction of nonpolar amino acid enzymes in the cytoplasm compared with charged and aromatic amino acid enzymes in the periplasm (Table 2). The peribacteroid space (Saalbach et al. 2002) and peribacteroid membrane (Catalano et al. 2004; Panter et al. 2000; Saalbach et al. 2002; Wienkoop and Saalbach 2003) contained very few proteins involved in amino acid metabolism. Not a single

Table 4. (continued from previous page)

\begin{tabular}{|c|c|c|c|c|}
\hline Protein identified & Accession & Location & $\begin{array}{l}\text { Unique peptides } \\
\text { (spectral counts) }^{\mathrm{a}}\end{array}$ & $\%$ coverage $^{b}$ \\
\hline $\begin{array}{l}\text { Ulp1 protease family protein (Arabidopsis } \\
\text { thaliana) }\end{array}$ & gi|15233485|ref|NP_192348.1| & Periplasm & 2(2) & 3 \\
\hline $\begin{array}{l}\text { Integral membrane protein, putative } \\
\text { (Arabidopsis thaliana) }\end{array}$ & gi|22331867|ref|NP_191491.2| & Periplasm & 2(2) & 13 \\
\hline Terpene synthase (Arabidopsis thaliana) & gi|29468412|gb|AAO85540.1| & Periplasm & $2(2)$ & 6 \\
\hline $\begin{array}{l}\text { Unnamed protein product (Arabidopsis } \\
\text { thaliana) }\end{array}$ & gi|10178025|dbj|BAB11477.1| & Periplasm & 2(2) & 6 \\
\hline $\begin{array}{l}\text { ATPU1 (Pullulanase 1); alpha-amylase/limit } \\
\text { dextrinase (Arabidopsis thaliana) }\end{array}$ & gi|30680478|ref|NP_196056.2| & Periplasm & 2(2) & 4 \\
\hline $\begin{array}{l}\text { Unnamed protein product (Arabidopsis } \\
\text { thaliana) }\end{array}$ & gi|9293869|dbj|BAB01772.1| & Periplasm & 2(2) & 8 \\
\hline $\begin{array}{l}\text { Chromomethylase } 2 \text { (CMT2) (Arabidopsis } \\
\text { thaliana) }\end{array}$ & gi|42566945|ref|NP_193637.2| & Periplasm & 2(2) & 3 \\
\hline $\begin{array}{l}\text { Disease resistance protein (TIR-NBS-LRR } \\
\text { class), putative (Arabidopsis thaliana) }\end{array}$ & gi|42563187|ref|NP_177429.2| & Periplasm & 2(2) & 5 \\
\hline $\begin{array}{l}\text { S-locus protein kinase, putative (Arabidopsis } \\
\text { thaliana) }\end{array}$ & gi|18407211|ref|NP_564777.1| & Periplasm & 2(2) & 6 \\
\hline $\begin{array}{l}\text { XTR6 (Xyloglucan endotranasglycosylase } \\
\text { 6); hydrolase, acting on glycosyl bonds } \\
\text { (Arabidopsis thaliana) }\end{array}$ & gi|15235997|ref|NP_194311.1| & Periplasm & 2(2) & 17 \\
\hline $\begin{array}{l}\text { Seed maturation family protein (Arabidopsis } \\
\text { thaliana) }\end{array}$ & gi|15238703|ref|NP_200139.1| & Periplasm & 2(2) & 36 \\
\hline $\begin{array}{l}\text { SDD1 (Stomatal density and distribution); } \\
\text { subtilase (Arabidopsis thaliana) }\end{array}$ & gi|18379242|ref|NP_563701.1| & Periplasm & 2(2) & 6 \\
\hline Kinesin-like protein (Arabidopsis thaliana) & gi|9294524|dbj|BAB02786.1| & Periplasm & $2(2)$ & 4 \\
\hline $\begin{array}{l}\text { Eukaryotic translation initiation factor } 2 \\
\text { subunit 3, putative/eIF2S3, putative/eIF-2- } \\
\text { gamma, putative (Arabidopsis thaliana) }\end{array}$ & gi|15224215|ref|NP_179462.1| & Periplasm & $2(2)$ & 6 \\
\hline $\begin{array}{l}\text { Putative Athila-like protein (Arabidopsis } \\
\text { thaliana) }\end{array}$ & gi|4309705|gb|AAD15489.1| & Periplasm & 2(2) & 14 \\
\hline Resistance protein PLTR (Arachis hypogaea) & gi|62361110|gb|AAX81234.1| & Periplasm & 2(2) & 21 \\
\hline Unknown protein (Arabidopsis thaliana) & gi|5903077|gb|AAD55635.1|AC008017_8 & Periplasm & 2(2) & 10 \\
\hline $\begin{array}{l}\text { ATGSL12 (Glucan synthase-like 12); 1,3- } \\
\text { beta-glucan synthase/transferase, } \\
\text { transferring glycosyl groups (Arabidopsis } \\
\text { thaliana) }\end{array}$ & gi|30684210|ref|NP_196804.2| & Cytoplasm & 2(2) & 2 \\
\hline $\begin{array}{l}\text { Protein kinase family protein (Arabidopsis } \\
\text { thaliana) }\end{array}$ & gi|42569078|ref|NP_179266.2| & Cytoplasm & 2(3) & 5 \\
\hline Unknown protein (Arabidopsis thaliana) & gi|26451927|dbj|BAC43056.1| & Cytoplasm & 2(2) & 8 \\
\hline Kinesin like protein (Arabidopsis thaliana) & gi| 2244790|emb|CAB 10212.1| & Cytoplasm & $2(2)$ & 4 \\
\hline $\begin{array}{l}\text { Copia-like retrotransposable element } \\
\text { (Arabidopsis thaliana) }\end{array}$ & gi| $|9294121| \mathrm{dbj}|\mathrm{BAB} 01972.1|$ & Cytoplasm & 2(2) & 3 \\
\hline $\begin{array}{l}\text { RPP13 (Recognition of Peronospora } \\
\text { parasitica 13); ATP binding (Arabidopsis } \\
\text { thaliana) }\end{array}$ & gi|15231449|ref|NP_190237.1| & Cytoplasm & 2(2) & 5 \\
\hline $\begin{array}{l}\text { TTL1 (Tetratricolpeptide-repeat thioredoxin- } \\
\text { like 1); binding (Arabidopsis thaliana) }\end{array}$ & gi|15219271|ref|NP_175737.1| & Cytoplasm & 2(2) & 8 \\
\hline $\begin{array}{l}\text { 60-kDa chaperonin (Protein Cpn60) (groEL } \\
\text { protein) }\end{array}$ & gi|6225132|sp|O66212|CH60_KLEPL & Both & $2(4) / 3(3)$ & 6 \\
\hline
\end{tabular}


unambiguous amino acid transporter has been identified by proteomic analysis of the peribacteroid membrane (Catalano et al. 2004; Panter et al. 2000; Saalbach et al. 2002; Wienkoop and Saalbach 2003). In contrast, the bacteroid has numerous amino acid transporters (Delmotte et al. 2010; Sarma and Emerich 2005). Amino acid cycles are necessary for effective nitrogen fixation in pea nodules (Lodwig et al. 2003; Prell and Poole 2006). Allaway et al. (2000) have demonstrated that R. leguminousarum mutants blocked in the transport of branched chain amino acids resulted in nitrogen-deficient pea plants. The disproportionate abundance of amino acid metabolic enzymes in the B. diazoefficiens bacteroid cytoplasm and periplasm (Table 2) (Delmotte et al. 2010; Sarma and Emerich 2005) relative to the lack of this class of proteins in the peribacteroid space and peribacteroid membrane in nodules of Medicago truncatula, Lotus japonicus, Pisum sativum, and Glycine max (Catalano et al. 2004; Panter et al. 2000; Saalbach et al. 2002; Wienkoop and Saalbach 2003) suggest a differentiation of amino acid metabolic activities among these symbiotic compartments. It also indicates the periplasm is distinct from the peribacteroid space.

Fatty acid biosynthesis and catabolism are known to occur in the cytoplasm of cultured bacteria (Zhang and Rock 2008).
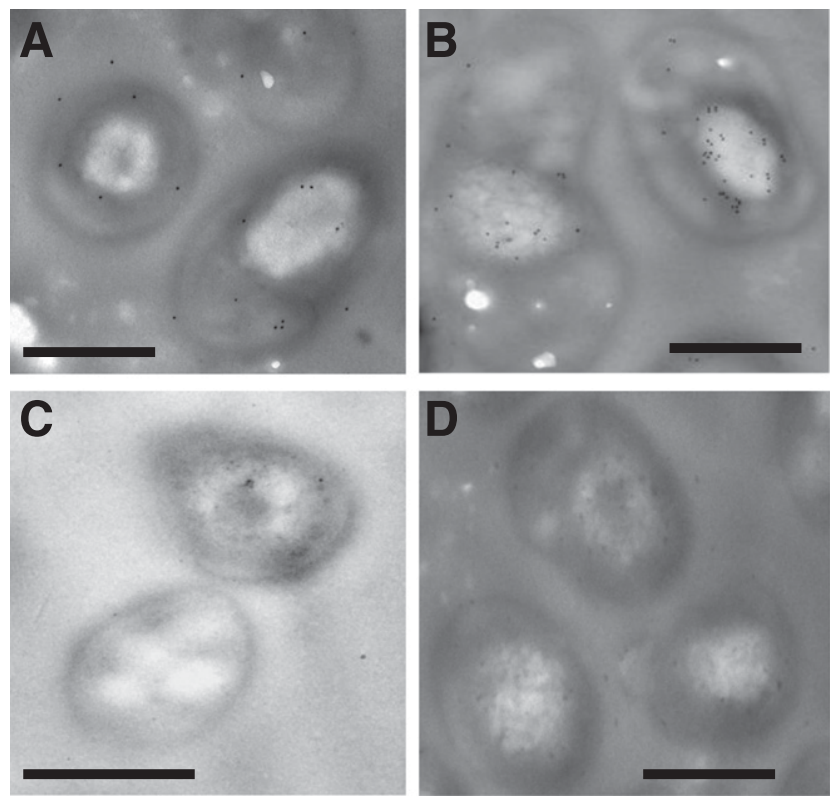

Fig. 2. Immunogold labeling of soybean nodule bacteroids. Each panel shows a grouping of bacteroids within an infected plant cell. A, Immunogold labeling with lipoxygenase antibody and B, with histone $\mathrm{H} 2 \mathrm{~A}$ antibody. $\mathbf{C}$, Control for lipoxygenase antibody and $\mathbf{D}$, for histone H2A antibody. The bar in each panel represents $1 \mu \mathrm{m}$.

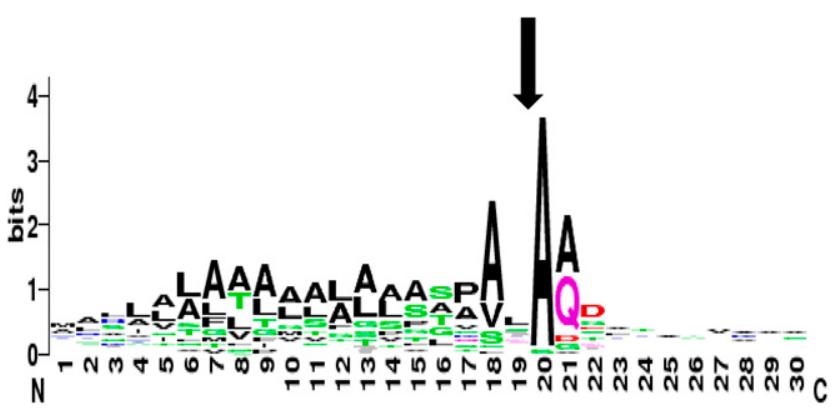

Fig. 3. The predicted leader sequence of proteins identified by Signal P. The predicted cut site is shown by the arrow (between amino acid residues 19 and 20).
However, the symbiotic form of B. diazoefficiens was found to have the enzymes of fatty acid metabolism predicted to occur in the bacteroid periplasm (Table 3). The peribacteroid space (Saalbach et al. 2002), peribacteroid membrane (Catalano et al. 2004; Panter et al. 2000; Saalbach et al. 2002; Wienkoop and Saalbach 2003), and the bacteroid cytoplasm (Sarma and Emerich 2005) had few enzymes of fatty acid and lipid metabolism. The unique assemblage of fatty acid metabolic enzymes in the bacteroid periplasm demonstrates the periplasm is a discrete symbiotic space and that the periplasm is not a continuum of the peribacteroid space and provides validation of the periplasm isolation technique.

Analysis of the amino acids in the periplasm showed phosphoethanolamine, phosphoserine, and glycine to be the most abundant (Table 5). Alanine (Waters et al. 1998) and glutamate (Green et al. 2000), which are produced under microaerobic conditions, were absent, as the bacteroids were isolated aerobically and the isolation procedure would remove or dilute residue amino acids not being actively produced in or transported to the periplasm. Thus, the presence of phosphoethanolamine, phosphoserine, and glycine demonstrate an active production in, or transport to, the periplasm. 3-Phosphoserine and serine are precursors of glycine, and the conversion of serine to glycine is catalyzed by serine hydroxymethyltransferase (bll5033). In addition, serine and cystathionine are precursors of cysteine; all three amino acids were found in the periplasm (Table 5). Both the peribacteroid membrane and the microsomal fraction of pea nodules had a greater concentration of phosphatidylcholine than phosphatidylethanolamine (Hernández and Cooke 1996) and phosphotidylcholine in the $B$. diazoefficiens membrane is needed for symbiosis with soybean (Minder et al. 2001). In plants, the phosphoethanolamine moiety is derived from serine by decarboxylation followed by phosphorylation. In bacteria, phosphocholine was thought to perform a special function, such as in the interaction of rhizobia with the plant host (Geiger 1998; Goldfine 1982; Miller et al. 1990). In microbes, it is formed from the decarboxylation of phosphoserine (Rontein et al. 2001). Although B. diazoefficiens does not have an annotated phosphoserine decarboxylase (Kaneko et al. 2002), a methyltransferase was localized to the periplasm (bll4939). The localization of fatty acid metabolic enzymes and the presence of phosphoserine, phophoethanolamine, and glycine, all of which were abundant in the periplasm, suggest that the bacteroid periplasm is the site of phospholipid metabolism.

The peribacteroid membrane is initially formed via endocytosis (Limpens et al. 2009) composed of the endoplasmic reticulum, the infection thread membrane, and de novo membrane from an unidentified source (Roth and Stacey 1989). The formation of peribacteroid membranes and their maintenance requires a massive amount of fatty acids. The bacteroid periplasm may be the source of de novo membrane material. The spatial and temporal distribution

Table 5. Amino acid composition of the periplasm of Bradyrhizobium diazoefficiens $^{\mathrm{a}}$

\begin{tabular}{lc}
\hline Compound & Results \\
\hline Phosphoserine & $1.23 \pm 0.23$ \\
Taurine & $8.12 \pm 0.35$ \\
Phosphoethanolamine & $3.69 \pm 0.49$ \\
Serine & $0.02 \pm 0.01$ \\
Glutamate & $0.03 \pm 0.01$ \\
Glycine & $1.17 \pm 0.18$ \\
Cysteine & $0.08 \pm 0.03$ \\
Isoleucine & $0.02 \pm 0.01$ \\
Tyrosine & $0.17 \pm 0.05$ \\
Cystathionine & $0.07 \pm 0.03$ \\
\hline
\end{tabular}

${ }^{a}$ Given in micrograms per sample and are the mean \pm standard deviation of six samples of periplasm $(200 \mu \mathrm{l}$ of periplasm per sample). Taurine was added as an internal standard. 
of lipids is tightly regulated and lipids have roles in regulating cellular development, intracellular signaling, membrane trafficking, and cargo sorting (Holthuis and Levine 2005). Thus, the periplasm may perform a major role in symbiosis.

$B$. diazoefficiens bacteroids have ample acetate production, as bacteroids can produce up to $60 \%$ of their dry weight as an acetate polymer, poly- $\beta$-hydroxybutyrate (PHB) (Karr et al. 1983). Acetate is produced from malate, which is the most abundant organic acid in the nodule (Stumpf and Burris 1981), via malic enzyme (Chen et al. 1998; Driscoll and Finan 1997) and the pyruvate dehydrogenase complex (Karr et al. 1984). A distinction between determinate (annual plants) and indeterminate (perennial plants) rhizobial symbiosis is the accumulation of PHB. In determinate symbioses with annual plants such soybean, the greatest need for production of de novo peribacteroid membrane is during peribacteroid compartment formation. Determinate nodules shift the fate of acetate from early peribacteroid membrane formation to later PHB formation. In indeterminate symbioses, with perennial plants, the need for de novo peribacteroid membrane persists throughout the lifetime of the nodule, which may divert acetate from potential PHB formation, to provide a continual supply of acetate for peribacteroid membrane. Also, in indeterminate nodules, at least those where a single bacteroid is enclosed within each peribacteroid, there is a close physical interaction between the peribacteroid and bacteroid membranes (Bradley et al. 1986; Bolaños et al. 2004).

Cevallos et al. (1996) have demonstrated that a PHB mutant of Rhizobium etli induced determinate nodules with prolonged capacity to fix nitrogen, perhaps via continued maintenance of the peribacteroid membrane without competition for PHB accumulation. In indeterminate nodules, Paau and Cowles (1978) have shown that PHB granules were present in Sinorhizobium meliloti cells inside infection threads, but they disappear when the cells are released into peribacteroids. If the bacteroid periplasm is necessary for membrane biogenesis and maintenance after release into peribacteroid sacs, then the bacteroids of indeterminate symbioses have the continuous metabolic responsibility of de novo membrane biosynthesis and, thus, do not contain PHB granules.

Surprisingly, about half of all the proteins isolated from the periplasm were identified as plant proteins. One of these proteins, identified as a soybean seed lipoxygenase, was determined to be a type 1 lipoxygenase, based on its activity at $\mathrm{pH} 9$ (Mohammadi and Karr 2003). Mohammadi and Karr (2003) and Junghans et al. (2004) found both type I and type II lipoxygenase activities in soybean nodules extracts, but neither group attempted to measure the activity in bacteroids. The presence of a type I but not type II lipoxygenase in the bacteroid periplasm suggests a differential compartmentation of soybean nodule lipoxygenases. Immunogold localization of antibodies to lipoxygenase and histone $\mathrm{H} 2 \mathrm{~A}$ correlated with their presence in the bacteroid periplasm. This implies that plant proteins may be transported across the peribacteroid membrane and peribacteroid space to the bacteroid surface to perform a significant role in periplasmic functioning during symbiosis. This is the first report of plant proteins localized to the bacteroid periplasm. Neither lipoxygenase nor histone $\mathrm{H} 2 \mathrm{~A}$ were identified in the peribacteroid space or peribacteroid membrane proteomes (Catalano et al. 2004; Panter et al. 2000; Saalbach et al. 2002; Wienkoop and Saalbach 2003). Histone H2A has previously been shown to be excreted from Pacific white shrimp (Patat et al. 2004), Atlantic cod (Bergsson et al. 2005), and pea root tips (Wen et al. 2007). When the 45 plant proteins identified in the bacteroid periplasm fraction are included with the annotated B. diazoefficiencs periplasmic proteins, the plant proteins comprise $>25 \%$ of the total proteins ascribed to the periplasm. This result supports the notion that the bacteroid periplasm is a true symbiotic, interkingdom space.

\section{Summary.}

The modified procedure of Streeter (1989) and Streeter and Le Rudulier (1990) and bioinformatics analysis combined to produce the first proteomic analysis of the B. diazoefficiens bacteroid periplasm. About $40 \%$ of all the proteins of the $B$. diazoefficiens genome annotated to be localized to the periplasm were found in bacteroids, suggesting an important role for this space in symbiotic function. Two of these roles appear to be fatty acid/phospholipid metabolism charged and aromatic amino acid metabolism. A total of 53 plant proteins were found in the periplasm fractions, and immunolocalization indicated that at least two of them may have been transported to the periplasm. The results indicate that the periplasm is a unique interkingdom symbiotic compartment with distinct metabolic functions.

\section{MATERIALS AND METHODS}

\section{Plant material.}

Soybean plants (Glycine max L. cv. Pioneer 93M11) were collected from University of Missouri-Columbia Bradford Research and Extension Center fields 56 days after planting. Nodules were removed from the roots and all dirt and root debris was removed, with washes in distilled water. Bacteroids were isolated from nodules as previously described (Karr et al. 1984).

\section{Periplasmic protein isolation.}

Bacteroids isolated from $30 \mathrm{~g}$ of nodules were aliquoted into three equal amounts and were resuspended in $10 \mathrm{ml}$ of $25 \mathrm{mM}$ citrate buffer, $\mathrm{pH} 4.0$, and were incubated at room temperature for $15 \mathrm{~min}$, followed by centrifugation at $12,000 \times g$ for $15 \mathrm{~min}$. The pellet was gently brought up into isolation buffer $(50 \mathrm{mM}$ Tris-HCl, pH 7.5, with 2 mM EDTA and 20\% [wt/vol] sucrose), using a \#4 tapered-tip artist paint brush. Ready-Lyse lysozyme solution (25,000 U) (Epicentre, Madison, WI, U.S.A.) and protease inhibitor cocktail $(10 \mu \mathrm{l})($ Calbiochem, Rockland, MA, U.S.A.) were added to the suspended bacteroids and were mixed gently, followed by incubation for $30 \mathrm{~min}$ at room temperature. The periplasm was collected by centrifugation at $12,000 \times g$ for $10 \mathrm{~min}$ at $4^{\circ} \mathrm{C}$ and the three fractions were combined. The three resulting bacteroid spheroplast fractions were combined and were suspended in $15 \mathrm{ml}$ of MEP buffer $\left(5 \mathrm{mM} \mathrm{MgCl}_{2}, 1 \mathrm{mM}\right.$ EDTA, 50 mM K-phosphate buffer, $\mathrm{pH}$ 7.0) containing $10 \mu \mathrm{l}$ of protease inhibitor cocktail and, then, were ruptured in the French press as previously described (Karr et al. 1984).

\section{Enzyme assays.}

The following enzymes were measured spectrophotometrically. Background rates were determined by a 2-min preincubation period of the complete reaction mixture minus the indicated substrate.

B-Hydroxybutyrate dehydrogenase. Assays contained $600 \mu \mathrm{M}$ $\mathrm{NAD}^{+}, 20 \mathrm{mM}$ sodium DL-hydroxybutyrate, $50 \mathrm{mM}$ TES, $\mathrm{pH}$ 7.9, and enzyme extract $(50 \mu \mathrm{l}$ of periplasmic fractions, $2.5 \mu \mathrm{l}$ of bacteroid cytosol fractions) in a 1-ml final volume. Hydroxybutyrate was added to begin the assay and the rate of NADH formation was measured at $340 \mathrm{~nm}$.

Malate dehydrogenase. Assays contained $0.20 \mathrm{mM} \mathrm{NADH}$, $0.50 \mathrm{mM}$ cis-oxaloacetate, $95 \mathrm{mM}$ potassium phosphate, $\mathrm{pH}$ 7.4 , and enzyme extract ( $50 \mu \mathrm{l}$ of periplasmic fractions, $2.5 \mu \mathrm{l}$ of bacteroid cytosol fractions) in a 1-ml final volume. Oxaloacetate was added to initiate the assay and the rate of NADH oxidation was measured at $340 \mathrm{~nm}$.

Isocitrate dehydrogenase. Assays contained $0.5 \mathrm{mM}$ DLisocitrate, $0.4 \mathrm{mM} \mathrm{NADP}{ }^{+}, 3.3 \mathrm{mM} \mathrm{MgCl} 2,10 \mathrm{mM}$ potassium phosphate, $\mathrm{pH} 7.4$, enzyme extract $(50 \mu \mathrm{l}$ of periplasmic fractions, $2.5 \mu \mathrm{l}$ of bacteroid cytosol fractions) in a 1-ml final 
volume. Isocitrate was added to initiate the reaction, and the rate of $\mathrm{NADP}^{+}$reduction was measured at $340 \mathrm{~nm}$.

Cyclic phosphodiesterase assay. Assays contained $68 \mathrm{mM}$ sodium acetate, $\mathrm{pH} 6.0,10 \mathrm{mM} \mathrm{MgCl} 2,2 \mathrm{mM} \mathrm{CoCl}_{2}, 0.73 \mathrm{mM}$ bis (p-nitrophenyl) phosphate, and enzyme extract $(50 \mu \mathrm{l}$ of periplasmic fractions, $2.5 \mu \mathrm{l}$ of bacteroid cytosol fractions) in a 5.0-ml final volume. The reaction was incubated at $30^{\circ} \mathrm{C}$, with $1 \mathrm{ml}$ aliquots of the assay being stopped with $2.0 \mathrm{ml}$ of $0.1 \mathrm{M} \mathrm{NaOH}$ at $0,15,30$, and $60 \mathrm{~min}$. Formation of p-nitrophenol was measured at $410 \mathrm{~nm}$.

Lipoxygenase assay. Lipoxygenase was measured in triplicate at both pH 6.5 and pH 9.0 as described by Mohammadi and Karr (2003).

\section{Protein isolation and identification.}

The bacteroid periplasmic and cytoplasmic protein fractions were each extracted using equal volumes of phenol saturated with $0.1 \mathrm{M}$ Tris- $\mathrm{HCl}, \mathrm{pH} 8.8$, and were mixed gently at room temperature for $1 \mathrm{~h}$, followed by centrifugation at $4,000 \times g$ for $10 \mathrm{~min}$ at $4^{\circ} \mathrm{C}$. The phenol phase was collected and four volumes of $100 \%$ methanol containing $0.1 \mathrm{M}$ ammonium acetate and $10 \mathrm{mM}$ dithiothreitol (DTT) were added. Protein was precipitated overnight at $-20^{\circ} \mathrm{C}$. Protein precipitate was collected by centrifugation at $4,000 \times g$ for $10 \mathrm{~min}$ at $4^{\circ} \mathrm{C}$. The protein pellet was washed once with the methanol, ammonium acetate, and DTT solution. The protein pellet was then washed three times with $90 \%$ ethanol containing $10 \mathrm{mM}$ DTT and, then, was stored in $90 \%$ ( $\mathrm{vol} / \mathrm{vol}$ ) ethanol/DTT at $-80^{\circ} \mathrm{C}$ overnight.

Precipitated proteins were collected by centrifugation at $4,000 \times$ $g$ and $4^{\circ} \mathrm{C}$. The pellet was dissolved in reconstitution buffer (30 mM Tris- $\mathrm{HCl}, 7 \mathrm{M}$ urea, $2 \mathrm{M}$ thiourea, 4\% [wt/vol] CHAPS (3[(3-cholamidopropoyl)dimethylammonio]-1-propane sulfonate) at $\mathrm{pH} 8.8$ ) by gentle vortexing for $1 \mathrm{~h}$. Samples were quantified using the method of Bradford (1976). A 20- $\mu$ g portion of protein from each sample was removed and was diluted to $1 \mu \mathrm{g} / \mu \mathrm{l}$ with reconstitution buffer. As an internal standard, $200 \mathrm{ng}$ of BSA was added to give a protein ratio of $1 \%(\mathrm{wt} / \mathrm{wt}) \mathrm{BSA}$ and protein.

Disulfide bonds were reduced with $10 \mathrm{mM}$ DTT $(100 \mathrm{mM}$ stock in $50 \mathrm{mM}$ ammonium bicarbonate), at $25^{\circ} \mathrm{C}$ for $1 \mathrm{~h}$. Reduced cysteines were alkylated with $40 \mathrm{mM}$ iodoacetamide (200 mM stock in $50 \mathrm{mM}$ ammonium bicarbonate), at $25^{\circ} \mathrm{C}$ in the dark for $1 \mathrm{~h}$. Iodoacetamide was quenched by adding additional DTT to $30 \mathrm{mM}(100 \mathrm{mM}$ stock in $50 \mathrm{mM}$ ammonium bicarbonate) and incubating at $25^{\circ} \mathrm{C}$ for $30 \mathrm{~min}$. Urea was brought to $1 \mathrm{M}$ by dilution with $50 \mathrm{mM}$ ammonium bicarbonate. Trypsin (sequencing grade modified) (Promega, Madison, WI, U.S.A.) was reconstituted to $0.02 \mu \mathrm{g} / \mu \mathrm{l}$ and was activated in the provided resuspension buffer per manufacturer's instructions, was then added to samples at a ratio of 1:200 (wt/wt) (trypsin/sample). Samples were incubated at $37^{\circ} \mathrm{C}$ for $16 \mathrm{~h}$. Digests were then lyophilized to dryness. There were three biological replications for both the periplasm and the cytoplasm.

\section{MS analysis.}

Lyophilized protein samples were reconstituted, in $100 \mu \mathrm{l}$ of $18 \mathrm{M} \Omega$ water with $0.1 \%$ ( vol $/ \mathrm{vol}$ ) formic acid and $5.0 \%$ ( vol/vol) acetonitrile, by pipetting and mild vortexing. Samples were spun at $13,000 \times g$ at $4^{\circ} \mathrm{C}$ for $10 \mathrm{~min}$ in a tabletop centrifuge, to remove insoluble debris. portions $(20 \mu \mathrm{l})$ from each sample were aliquoted into a polypropylene 96 -well plate, were covered with adhesive film and briefly centrifuged to collect samples at the bottom of the well, and were placed in the LC autosampler. For analysis, $10-\mu \mathrm{l}$ injections were run on a LTQ ProteomeX linear ion trap LC-MS/MS instrument (Thermo Fisher, San Jose, CA, U.S.A.). Peptides were concentrated and desalted on in-line $\mathrm{C}_{8}$ captraps (Michrom Bioresources, Auburn, CA, U.S.A.), prior to final separation by a $\mathrm{C}_{18}$ column, using an acetonitrile gradient of 0 to $90 \%$ solvent B $(100 \%$ acetonitrile with $0.1 \%$ [vol/vol] formic acid), in solvent A (deionized $18 \mathrm{M} \Omega$ water with $0.1 \%$ [vol/vol] formic acid) for a duration of $110 \mathrm{~min}$. The peptide trap and $\mathrm{C}_{18}$ column were then re-equilibrated for 25 min with $100 \%$ solvent A before applying the next sample.

LC separation was performed using fused silica nanospray needles, $26 \mathrm{~cm}$ in length $(360 \mu \mathrm{m}$ outer diameter, $150 \mu \mathrm{m}$ inner diameter) (Polymicro Technologies, Phoenix, AZ, U.S.A.) that were packed with Magic C18 (200 A, $5 \mu$ m particles) (Michrom Bioresources) in $100 \%$ methanol. Before sample acquisition, columns were equilibrated for 3 to $4 \mathrm{~h}$ at $200 \mathrm{nl} / \mathrm{min}$ (at the column tip) with a 60:40 mix of solvent B to solvent A. Samples were analyzed in the data-dependent positive acquisition mode on the LC-MS/MS instrument, using normal scan rate for precursor ion analysis, and dynamic exclusion enabled (one repeat count, $30 \mathrm{~s}$ repeat duration, list size of 50 , and $30 \mathrm{~s}$ exclusion). Following each full scan (400 to 2,000 m/z), a data-dependent triggered MS/MS scan for the three most intense parent ions were acquired. The nanospray column was held at ion sprays of $2.0 \mathrm{kV}$. There were two technical replicates per biological sample.

\section{Database searching and spectral analysis.}

Tandem mass spectra were extracted by BioWorks version 3.3. All MS/MS samples were analyzed using SEQUEST (ThermoFinnigan, version 2.7; San Jose, CA, U.S.A.). SEQUEST was set up to search a FASTA formatted protein database of translated potential coding regions of the Bradyrhizobium japonicum genome, provided by the Kazusa DNA Research Institute RhizoBase website, indexed for trypsin digestion. All available plant genome databases were searched. Data mining was performed with a fragment ion mass tolerance of $1.0 \mathrm{Da}$ and a parent ion tolerance of 2.0 Da. Iodoacetamide derivative of cysteine $(+57)$ was specified in SEQUEST as a fixed modification. RAW files were searched using Bioworks "SEQUEST batch-search". The search results file (.srf) were imported into Scaffold (Proteome Software, release 2.0; Portland, OR, U.S.A.) and were analyzed as described below. The false discovery rate is approximately $0.3 \%$.

\section{Spectral counting and quantitation by scaffold.}

Scaffold (Proteome Software, release 2.0) was used to validate MS/MS-based peptide and protein identifications. Peptide identifications were accepted if they could be established at greater than $95.0 \%$ probability, as specified by the peptide prophet algorithm (Keller et al. 2002). Protein identifications were accepted if they could be established at greater than $99.0 \%$ probability and contained at least two identified peptides. The $t$ test function of Scaffold was used to predict $P$ values for observed differences for each identified protein. Proteins with a $P$ value of $\leq 0.05$ are indicated in each of the tables with a superscript $\mathrm{P}$. Protein probabilities were assigned by the protein prophet algorithm (Nesvizhskii et al. 2003). The tables contain the greatest peptide number and percent coverage of six analyses (three biological samples, two technical replicates per biological sample).

\section{Protein localization analysis.}

Protein localization was performed via the computational prediction program database, cPSORTdb.

\section{Protein leader sequence analysis.}

Protein leader sequences was determined by computational prediction program Signal P.

\section{Amino acid analysis.}

Amino acid analysis was performed at the Chemical Laboratory of the Agricultural Experiment Station at the University of Missouri, using Hitachi L-8900 amino acid analyzers. 


\section{Western blotting.}

Antibodies for histone H2A were purchased from Santa Cruz Biotechnology. Western blot analysis was performed as described previously (Karr et al. 2000). The lipoxygenase polyclonal antibodies were prepared by J. C. Polacco, with the assistance of the Laboratory Animal Medicine Office at the University of Missouri-Columbia School of Medicine, and were partially purified by ammonium sulfate fractionation and DEAE Affi-gel blue chromatography before use (Waters et al. 1985).

\section{Immunogold labeling and electron microscopy.}

Immunogold sample preparation was performed (Skepper and Powell 2008) by the Electron Microscopy Facility at the University of Missouri and were visualized on a JEOL 1400 transmission electron microscope.

\section{ACKNOWLEDGMENTS}

This research was supported by grant 2004-35604-14708 from the United States Department of Agriculture Cooperative State Research Education and Extension Service National Research Initiative.

\section{LITERATURE CITED}

Allaway, D., Lodwig, E. M., Crompton, L. A., Wood, M., Parsons, R., Wheeler, T. R., and Poole, P. S. 2000. Identification of alanine dehydrogenase and its role in mixed secretion of ammonium and alanine by pea bacteroids. Mol. Microbiol. 36:508-515.

Ames, G. F.-L. 1988. Structure and mechanism of bacterial periplasmic transport systems. J. Bioenerg. Biomembr. 20:1-18.

Anthon, G.E., and Emerich, D.W. 1990. Developmental regulation of enzymes of sucrose and hexose metabolism in effective and ineffective nodules. Plant Physiol. 92:346-351.

Artier, J., da Silva Zandonadi, F., Carvallo, F. M., Pauletti, B. A., Leme, A. F., Carnielli, C. M., Selistre-de-Araujo, H. S., Bertolini, M. C., Ferro, J. A., Belasque Júnior, J., de Oliveira, J. C., and Novo-Mansur, M. T. 2017. Comparative proteomic analysis of Xanthomonas citri ssp. citri periplasmic proteins reveals changes in cellular envelope metabolism during in vitro pathogenicity induction. Mol. Plant Pathol. doi:10.1111/mpp.12507

Bergersen, F. J. 1982. Page 164 in: Root Nodules of Legumes: Structure and Functions. Research Studies Press, Letchworth, England.

Bergsson, G., Agerberth, B., Jörnvall, H., and Gudmundsson, G. H. 2005. Isolation and identification of antimicrobial components from the epidermal mucus of Atlantic cod (Gadus morhua). FEBS J. 272:4960-4969.

Bernardelli, C. E., Luna, M. F., Galar, M. L., and Boiardi, J. L. 2001. Periplasmic PQQ-dependent glucose oxidation in free-living and symbiotic rhizobia. Curr. Microbiol. 42:310-315.

Bolaños, L., Redondo-Nieto, M., Rivilla, R., Brewin, N. J., and Bonilla, I. 2004. Cell surface interactions of Rhizobium bacteroids and other bacterial strains with symbiosomal and peribacteroid membrane components from pea nodules. Mol. Plant-Microbe Interact. 17:216-223.

Bradford, M. M. 1976. A rapid and sensitive method for the quantitation of microgram quantities of protein utilizing the principle of protein-dye binding. Anal. Biochem. 72:248-254.

Bradley, D. J., Butcher, G. W., Galfre, G., Wood, E. A., and Brewin, N. J. 1986. Physical association between the peribacteroid membrane and lipopolysaccharide from the bacteroid outer membrane in Rhizobiuminfected pea root nodule cells. J. Cell Sci. 85:47-61.

Catalano, C. M., Lane, W. S., and Sherrier, D. J. 2004. Biochemical characterization of symbiosome membrane proteins from Medicago truncatula root nodules. Electrophoresis 25:519-531.

Cevallos, M. A., Encarnación, S., Leija, A., Mora, Y., and Mora, J. 1996. Genetic and physiological characterization of a Rhizobium etli mutant strain unable to synthesize poly- $\beta$-hydroxybutyrate. J. Bacteriol. 178:1646-1654.

Chen, F., Okabe, Y., Osano, K., and Tajima, S. 1998. Purification and characterization of an NAD-malic enzyme from Bradyrhizobium japonicum A1017. Appl. Environ. Microbiol. 64:4073-4075.

Copeland, L., Vella, J., and Hong, Z. 1989. Enzyme of carbohydrate metabolism in soybean nodules. Phytochemistry 28:57-61.

da Silva Batista, J. S., Torres, A. R., and Hungria, M. 2010. Towards a twodimensional proteomic reference map of Bradyrhizobium japonicum CPAC 15: Spotlighting "hypothetical proteins". Proteomics 10: 3176-3189. de Maagd, R. A., and Lugtenberg, B. 1986. Fractionation of Rhizobium leguminosarum cells into outer membrane, cytoplasmic membrane, periplasmic, and cytoplasmic components. J. Bacteriol. 167:1083-1085

Delamuta, J.R., Riberio, R.A., Ormeno-Orillo, E., Melo, I.S., Martinez-Romero, E., and Hungria, M. 2013. Polyphasic evidence supporting the reclassification of the Bradyrhizobium japonicum group 1a strains as Bradyrhizobium diazoefficiens sp. nov. Int. J. Syst. Evol. Microbiol. 63:3342-3351.

Delgado, M. J., Bonnard, N., Tresierra-Ayala, A., Bedmar, E. J., and Müller, P. 2003. The Bradyrhizobium japonicum napEDABC genes encoding the periplasmic nitrate reductase are essential for nitrate respiration. Microbiology 149:3395-3403.

Delmotte, N., Ahrens, C. H., Knief, C., Qeli, E., Koch, M., Fischer, H. M., Vorholt, J. A., Hennecke, H., and Pessi, G. 2010. An integrated proteomics and transcriptomics reference data set provides new insights into the Bradyrhizobium japonicum bacteroid metabolism in soybean root nodules. Proteomics 10:1391-1400.

Driscoll, B. T., and Finan, T. M. 1997. Properties of $\left.\mathrm{NAD}^{+}\right)$- and NADP $\left({ }^{+}\right)$-dependent malic enzymes of Rhizobium (Sinorhizobium) meliloti and differential expression of their genes in nitrogen-fixing bacteroids. Microbiology 143:489-498.

Emerich, D. W., and Krishnan, H. B. 2014. Symbiosomes: Temporary moonlighting organelles. Biochem. J. 460:1-11.

Fani, R., Gallo, R., and Liò, P. 2000. Molecular evolution of nitrogen fixation: The evolutionary history of the nifD, nifK, nifE, and nifN genes. J. Mol. Evol. 51:1-11.

Fennel, K., Follows, M., and Falkowski, P. G. 2005. The co-evolution of the nitrogen, carbon and oxygen cycles in the Proterozoic ocean. Am. J. Sci. 305:526-545.

Franzén, B., Becker, S., Mikkola, R., Tidblad, K., Tjernberg, A., and Birnbaum, S. 1999. Characterization of periplasmic Escherichia coli protein expression at high cell densities. Electrophoresis 20:790-797.

Geiger, O. 1998. Phospholipids and alternataive membrane lipids. Pages 55-80 in: The Rhizobiaceae. Molecular Biology of the Model PlantAssociated Bacteria. H. P. Spaink, A. Kondorosi, and P. J. J. Hooykaas, eds. Kluwer Academic Publishers, Dordrecht, The Netherlands.

Glenn, A. R., and Dilworth, M. J. 1979. An examination of Rhizobium leguminosarum for the production of extracellular and periplasmic proteins. J. Gen. Microbiol. 112:405-409.

Goldfine, H. 1982. Lipids of prokaryotes: Structure and distribution. Curr. Top. Membr. Transp. 17:1-43.

Green, L. S., Li, Y., Emerich, D. W., Bergersen, F. J., and Day, D. A. 2000 Catabolism of $\alpha$-ketoglutarate by a sucA mutant of Bradyrhizobium japonicum: Evidence for an alternative tricarboxylic acid cycle. J. Bacteriol. 182:2838-2844.

Heazlewood, J. L., Tonti-Filippini, J., Verboom, R. E., and Millar, A. H. 2005. Combining experimental and predicted datasets for determination of the subcellular location of proteins in Arabidopsis. Plant Physiol. 139: 598-609.

Heidary, S., Rahim, R. A., Eissazadeh, S., Moeini, H., Chor, A. L. T., and Abdullah, M. P. 2014. Proteome analysis of Escherichia coli periplasmic proteins in response to over-expression of recombinant human interferon $\alpha 2 b$. Biotechnol. Lett. 36:1479-1484.

Hempel, J., Zehner, S., Göttfert, M., and Patschkowski, T. 2009. Analysis of the secretome of the soybean symbiont Bradyrhizobium japonicum. J. Biotechnol. 140:51-58.

Henderson, B., and Martin, A. 2011. Bacterial virulence in the moonlight: Multitasking bacterial moonlighting proteins are virulence determinants in infectious disease. Infect. Immun. 79:3476-3491.

Hernández, L.E., and Cooke, D.T. 1996. Lipid composition of symbiosomes from pea root nodules. Phytochemistry 42:341-346.

Holthuis, J. C. M., and Levine, T. P. 2005. Lipid traffic: Floppy drives and a superhighway. Nat. Rev. Mol. Cell Biol. 6:209-220.

Imperi, F., Ciccosanti, F., Perdomo, A. B., Tiburzi, F., Mancone, C., Alonzi, T., Ascenzi, P., Piacentini, M., Visca, P., and Fimia, G. M. 2009. Analysis of the periplasmic proteome of Pseudomonas aeruginosa, a metabolically versatile opportunistic pathogen. Proteomics 9:1901-1915.

Jeffery, C. J. 1999. Moonlighting proteins. Trends Biochem. Sci. 24:8-11. Junghans, T. G., de Almeida Oliveira, M. G., and Moreira, M. A. 2004. Lipoxygenase activities during development of root and nodule of soybean. Pesq. Agropec. Bras. 39:625-630.

Kaneko, T., Nakamura, Y., Sato, S., Minamisawa, K., Uchiumi, T., Sasamoto, S., Watanabe, A., Idesawa, K., Iriguchi, M., Kawashima, K., Kohara, M., Matsumoto, M., Shimpo, S., Tsuruoka, H., Wada, T., Yamada, M., and Tabata, S. 2002. Complete genomic sequence of nitrogen-fixing symbiotic bacterium Bradyrhizobium japonicum USDA110. DNA Res. 9:189-197.

Karr, D. B., Liang, R.-T., Reuhs, B. L., and Emerich, D. W. 2000. Altered exopolysaccharides of Bradyrhizobium japonicum mutants correlate 
with impaired soybean lectin binding, but not with effective nodule formation. Planta 211:218-226.

Karr, D. B., Waters, J. K., and Emerich, D. W. 1983. Analysis of poly$\beta$-hydroxybutyrate in Rhizobium japonicum bacteroids by ion exclusion HPLC and UV detection. Appl. Environ. Microbiol. 46:1339-1343.

Karr, D. B., Waters, J. K., Suzuki, F., and Emerich, D. W. 1984. Enzymes of the $\beta$-hydroxybutyrate and citric acid cycles of Rhizobium japonicum bacteroids. Plant Physiol. 75:1158-1162.

Kasting, J. F., and Siefert, J. L. 2001. Biogeochemistry. The nitrogen fix. Nature 412:26-27.

Keller, A., Nesvizhskii, A. I., Kolker, E., and Aebersold, R. 2002. Empirical statistical model to estimate the accuracy of peptide identifications made by MS/MS and database search. Anal. Chem. 74:5383-5392.

Koch, M., Delmotte, N., Rehrauer, H., Vorholt, J. A., Pessi, G., and Hennecke, H. 2010. Rhizobial adaptation to hosts, a new facet in the legume root-nodule symbiosis. Mol. Plant-Microbe Interact.23:784-790.

Kouchi, H., Fukai, K., Katagin, H., Minamisawa, K., and Tajima, S. 1988. Isolation and enzymological characterization of infected and uninfected cell protoplasts from root nodules of Glycine max. Physiol. Plant. 73:327-334.

Limpens, E., Ivanov, S., van Esse, W., Voets, G., Fedorova, E., and Bisseling, T. 2009. Medicago $\mathrm{N}_{2}$-fixing symbiosomes acquire the endocytic identity marker Rab7 but delay the acquisition of vacuolar identity. Plant Cell 21:2811-2828.

Lodwig, E. M., Hosie, A. H., Bourdès, A., Findlay, K., Allaway, D., Karunakaran, R., Downie, J. A., and Poole, P. S. 2003. Amino-acid cycling drives nitrogen fixation in the legume-Rhizobium symbiosis. Nature 422:722-726.

Meakin, G. E., Bueno, E., Jepson, B., Bedmar, E. J., Richardson, D. J., and Delgado, M. J. 2007. The contribution of bacteroidal nitrate and nitrite reduction to the formation of nitrosylleghaemoglobin complexes in soybean root nodules. Microbiology 153:411-419.

Miller, K. J., Shon, B. C., Fore, R. S. and Hunt, W. P. 1990. The phospholipid composition of Bradyrhizobium spp. Curr. Microbiol. 21:205-210.

Minder, A. C., de Rudder, K. E. E., Narberhaus, F., Fischer, H.-M., Hennecke, H., and Geiger, O. 2001. Phosphatidylcholine levels in Bradyrhizobium japonicum membranes are critical for an efficient symbiosis with the soybean host plant. Mol. Microbiol. 39:1186-1198.

Mohammadi, M., and Karr, A. L. 2003. Induced lipoxygenases in soybean root nodules. Plant Sci. 164:471-479.

Nesvizhskii, A. I., Keller, A., Kolker, E., and Aebersold, R. 2003. A statistical model for identifying proteins by tandem mass spectrometry. Anal. Chem. 75:4646-4658.

Oehrle, N. W., Sarma, A. D., Waters, J. K., and Emerich, D. W. 2008. Proteomic analysis of soybean nodule cytosol. Phytochemistry 69:2426-2438.

Paau, A. S., and Cowles, J. R. 1978. Development of bacteroids in alfalfa (Medicago sativum). Plant Physiol. 178:1646-1654.

Panter, S., Thomson, R., de Bruxelles, G., Laver, D., Trevaskis, B., and Udvardi, M. 2000. Identification with proteomics of novel proteins associated with the peribacteroid membrane of soybean root nodules. Mol. Plant-Microbe Interact.13:325-333.

Patat, S. A., Carnegie, R. B., Kingsbury, C., Gross, P. S., Chapman, R., and Schey, K. L. 2004. Antimicrobial activity of histones from hemocytes of the Pacific white shrimp. Eur. J. Biochem. 271:4825-4833.

Prell, J., and Poole, P. 2006. Metabolic changes of rhizobia in legume nodules. Trends Microbiol. 14:161-168.

Quan, S., Hiniker, A., Collet, J.-F., and Bardwell, J. C. A. 2013. Bacterial Cell Surfaces: Methods and Protocols. Pages 359-366 in:
Methods in Molecular Biology. A. H. Delcour, ed. Springer, New York, NY.

Rontein, D., Nishida, I., Tashiro, G., Yoshioka, K., Wu, W.-I., Voelker, D. R., Basset, G., and Hanson, A. D. 2001. Plants synthesize ethanolamine by direct decarboxylation of serine using a pyridoxal phosphate enzyme. J. Biol. Chem. 276:35523-35529.

Roth, L. E., and Stacey, G. 1989. Bacterium release into host cells of nitrogen-fixing soybean nodules: The symbiosome membrane comes from three sources. Eur. J. Cell Biol. 49:13-23.

Saalbach, G., Erik, P., and Wienkoop, S. 2002. Characterisation by proteomics of peribacteroid space and peribacteroid membrane preparations from pea (Pisum sativum) symbiosomes. Proteomics 2:325-337.

Sarma, A. D., and Emerich, D. W. 2005. Global protein expression pattern of Bradyrhizobium japonicum bacteroids: A prelude to functional proteomics. Proteomics 5:4170-4184.

Sarma, A. D., and Emerich, D. W. 2006. A comparative proteomic evaluation of culture grown vs nodule isolated Bradyrhizobium japonicum. Proteomics 6:3008-3028.

Skepper, J. N., and Powell, J. M. 2008. Immunogold staining of expoxy resin sections for transmission electron microscopy. Cold Spring Harb Prot. 3.

Streeter, J. G. 1989. Analysis of periplasmic enzymes in intact cultured bacteria and bacteroids of Bradyrhizobium japonicum and Rhizobium leguminosarum biovar phaseoli. J. Gen. Microbiol. 135:3477-3484.

Streeter, J. G., and Le Rudulier, D. 1990. Release of periplasmic enzymes from Rhizobium leguminosarum bv phaseoli bacteroids by lysozyme is enhanced by pretreatment of cells by low pH. Curr. Microbiol. 21:169-173.

Stumpf, D. K., and Burris, R. H. 1981. Organic Acid contents of soybean: Age and source of nitrogen. Plant Physiol. 68:989-991.

Waters, J. K., Hughes, B. L., 2nd, Purcell, L. C., Gerhardt, K. O., Mawhinney, T. P., and Emerich, D. W. 1998. Alanine, not ammonia, is excreted from $\mathrm{N}_{2}$-fixing soybean nodule bacteroids. Proc. Natl. Acad. Sci. U.S.A. 95:12038-12042.

Waters, J. K., Karr, D. B., and Emerich, D. W. 1985. Malate dehydrogenase from Rhizobium japonicum 3I1b-143 bacteroids and Glycine max rootnodule mitochondria. Biochem. 24:6479-6486.

Wen, F., VanEtten, H. D., Tsaprailis, G., and Hawes, M. C. 2007. Extracellular proteins in pea root tip and border cell exudates. Plant Physiol. 143:773-783.

Wienkoop, S., and Saalbach, G. 2003. Proteome analysis. Novel proteins identified at the peribacteroid membrane from Lotus japonicus root nodules. Plant Physiol. 131:102.015362.

Zhang, Y.-M., and Rock, C. O. 2008. Membrane lipid homeostasis in bacteria. Nat. Rev. Microbiol. 6:222-233.

\section{AUTHOR-RECOMMENDED INTERNET RESOURCES}

cPSORT database: http://db.psort.org

Kazusa DNA Research Institute RhizoBase Bradyrhizobium japonicus database: http://genome.microbedb.jp/rhizobase/Bradyrhizobium

Signal P server: http://www.cbs.dtu.dk/services/SignalP

University of Missouri amino acid analyses website: http://www.aescl.missouri.edu/AminoAcids.html

University of Missouri Electron Microscopy Facility: http://www.emc.missouri.edu 